\title{
Relationships Between Some Physical-Chemical Properties and Nutrient Content of Wheat Cultivating Soils of Büyük Menderes Basin
}

\author{
Seda Erdoğan Bayram ${ }^{1, a, *}$ \\ ${ }^{1}$ Agricultural Faculty, Ege University 35040 İzmir, Turkey
} ${ }^{*}$ Corresponding author

\begin{tabular}{l|l}
\hline A R T ICLE IN F O \\
\hline Research Article
\end{tabular}

Received : 10/08/2021

Accepted : 26/10/2021

Keywords:

Büyük Menderes Basin

Soil analysis

Fertility

Wheat

Physico-chemical properties

A B S T R A C T

This study was conducted to examine the soil fertility of the Büyük Menderes Basin, where wheat is widely cultivated. Soil samples were taken from 50 different points at a depth of $0-30 \mathrm{~cm}$ and various physical and chemical properties and amounts of nutrient elements were determined. With regard to the results of the study, the soils were generally sandy-clay-loam in texture, with slightly alkaline reaction, limy, rich in organic matter and showed no risk of salinity. The examined soils were found to be insufficient as $34 \%$ for total N, $14 \%$ for available $\mathrm{K}, 26 \% \mathrm{Mg}, 10 \% \mathrm{Fe}, 94 \% \mathrm{Zn}$ and $98 \% \mathrm{Mn}$ contents while all of the soils were determined as sufficient in terms of available $\mathrm{P}, \mathrm{Cu}$ and $\mathrm{Ca}$ contents. When relationships between nutrient elements and soil physical-chemical properties were examined, negative correlations were found between soil $\mathrm{pH}$ and $\mathrm{EC}$, organic matter, total $\mathrm{N}$, available $\mathrm{K}, \mathrm{Zn}$; lime contents and available $\mathrm{Mg}$, $\mathrm{Fe}, \mathrm{Cu}$; clay and available $\mathrm{K}$ and $\mathrm{Mn}$ contents. The positive correlations were found between $\mathrm{EC}$ and available $\mathrm{K}, \mathrm{Ca}$ and $\mathrm{Zn}$; organic matter \% and total $\mathrm{N}$, available $\mathrm{K}, \mathrm{Cu}, \mathrm{Zn}$ and $\mathrm{Mn}$; sand $\%$ and available $\mathrm{Mn}$; clay $\%$ and available Fe contents. Investigation of relationships between plant nutrients demonstrated that, there were positive correlations between total $\mathrm{N}$ and available $\mathrm{K}, \mathrm{Cu}, \mathrm{Zn}, \mathrm{Mn}$; available $\mathrm{P}$ and $\mathrm{Zn}$; available $\mathrm{K}$ and $\mathrm{Cu}$, $\mathrm{Zn}, \mathrm{Mn}$; available $\mathrm{Ca}$ and $\mathrm{Fe}$; available $\mathrm{Mg}$ and $\mathrm{Fe}, \mathrm{Cu}$; available $\mathrm{Fe}$ and $\mathrm{Cu}, \mathrm{Mn}$; available $\mathrm{Cu}$ and Mn contents. The results of the study showed that attention should be paid to fertilization programs to fertilization with $\mathrm{Zn}$ and $\mathrm{Mn}$, which were found to be insufficient in the greater part of the basin's soils, and also to nitrogen deficiency is observed, as this directly affects the protein content of wheat.

Türk Tarım - G1da Bilim ve Teknoloji Dergisi, 9(12): 2272-2277, 2021

\section{Büyük Menderes Havzası Buğday Tarımı Yapılan Toprakların Bazı Fiziksel- Kimyasal Özellikleri ile Besin Elementi İçerikleri Arasındaki İlişkiler}

\begin{tabular}{l} 
M A K A L E B İ L G \\
\hline Araştırma Makalesi \\
\\
Geliş $\quad: 10 / 08 / 2021$ \\
Kabul $\quad: 26 / 10 / 2021$
\end{tabular}

Anahtar Kelimeler: Büyük Menderes Havzası Toprak analizleri Verimlilik Buğday Fizikokimyasal özellikler Ö Z

$\mathrm{Bu}$ çalışma, yaygın buğday tarımı yapılan Büyük Menderes Havzası topraklarının verimlilik durumlarının belirlenmesi amacıyla yapılmıştır. 50 farklı noktadan 0-30 cm derinlikten alınan toprak örneklerinin bazı fiziksel-kimyasal özellikleri ve besin elementi miktarları belirlenmiştir. Araştırma sonuçları toprakların; genel olarak kumlu-killi-tın bünyeli, hafif alkalin reaksiyonlu, kireçli, organik maddece zengin ve tuzluluk yönünden herhangi bir tehlike içermediğini göstermektedir. İncelenen toprakların \%34' ünün toplam N, \%14' ünün alınabilir K, \%26'sının Mg, \%10'unun Fe, \% 94'ünün $\mathrm{Zn}$ ve \%98'inin $\mathrm{Mn}$ içerikleri yetersiz bulunurken, toprakların tümü alınabilir $\mathrm{P}, \mathrm{Cu}$ ve $\mathrm{Ca}$ içerikleri yönüyle yeterli bulunmuştur. Toprak fiziksel-kimyasal özellikleri ile besin elementleri arasındaki ilişkiler incelendiğinde; $\mathrm{pH}$ ile EC, organik madde, toplam N, alınabilir K ve Zn; kireç ile $\mathrm{Mg}, \mathrm{Fe}$ ve $\mathrm{Cu}$; kil ile $\mathrm{K}$ ve Mn içerikleri arasında negatif; EC ile K, Ca ve $\mathrm{Zn}$; organik madde ile $\mathrm{N}, \mathrm{K}, \mathrm{Cu}, \mathrm{Zn}$ ve Mn; Kum ile Mn; Kil ile Fe içerikleri arasında pozitif korelasyonlar saptanmıştır. Besin elementlerinin birbirleriyle ilişkileri irdelendiğinde; $\mathrm{N}$ ile $\mathrm{K}, \mathrm{Cu}, \mathrm{Zn}$ ve $\mathrm{Mn}$; P ile $\mathrm{Zn}$; $\mathrm{K}$ ile $\mathrm{Cu}, \mathrm{Zn}$ ve $\mathrm{Mn}$; $\mathrm{Ca}$ ile $\mathrm{Fe}$; $\mathrm{Mg}$ ile $\mathrm{Fe}, \mathrm{Cu}$; $\mathrm{Fe}$ ile $\mathrm{Cu} ; \mathrm{Cu}$ ile $\mathrm{Mn}$ içerikleri arasında pozitif korelasyonlar saptanmıştır. Araştırma sonuçlarımız, gübreleme programlarında buğday bitkisinin protein içeriğini direkt etkilemesi yönüyle azot noksanlığı görülen arazilerde azotlu gübreleme ile havza topraklarının çok büyük bir kısmında yetersiz bulunan $\mathrm{Zn}$ ve $\mathrm{Mn}$ gübrelemelerine dikkat edilmesi gerektiğine işaret etmektedir. 


\section{Introduction}

Nowadays, global warming, increasing population, decreases in water resources and agricultural lands, uptake of nutrient elements from the soil continuously by plants, unconscious use of chemical fertilizers are necessitating the continuity of agricultural production by protecting the current soil and water resources. Sustainability of agricultural production, could be possible by protection and increase of soil fertility besides increasing the yield and quality of the crop be obtained. Increment of yield and quality could be provided by determining the relationships between physico-chemical properties of soils and keeping them at the optimum level.

Correct prediction of soil features and the relationship between these features is the basic factor that determined many processes from choosing the crop to the utilization of input. The presence of nutrient elements at insufficient or excessive levels in soil that necessary for plants during the agricultural production process, give rise to yield losses by limiting the utilization of nutrient elements by plants (Turan et al., 2010; Karaman, 2012). For this purpose, many investigations had been conducted and being carried on in different ecologies with different crop patterns.

Büyük Menderes basin which is one of the important agricultural lands of Turkey, comprises very large plains beginning from Denizli province and extending to the Aegean coasts. Owing to ecological characteristics, the basin, which makes significant contributions to the agriculture of the Aegean Region and Turkey and is highly productive where intensive agriculture is made, is $3.5 \%$ of Turkey's total surface area and shows diversity in terms of product pattern.

According to 2019 data, in the world where wheat is grown on approximately 216 million hectares of land. Turkey which has $3.24 \%$ of the total wheat planted area with 6.83 million hectares. In this distribution, wheat cultivation areas of Turkey account for approximately $66.9 \%$ of grain cultivated areas (FAO, 2021). Aegean region, has still provided nearly $8.1 \%$ of the total wheat production of the country. The greatest share in the region, with $36 \%$, consists of the soils of Büyük Menderes Basin, which includes the provinces Afyon and Uşak, where the dry farming system comes to the forefront due to its climatic conditions and crop production is mostly based on field crops (Genç, 2004).

Düzbast1lar (1984) reported that Büyük Menderes Basin's soils were generally loamy, salt-free ( $88 \%)$, high in lime contents $(85 \%)$ while contents of organic matter were very low. The greatest part of the basin soils had a loamy texture, slight-medium alkaline reaction, had not the risk of salinity and they were poor in organic matter with low lime content. Moreover, these soils were low in available potassium, medium/adequate in nitrogen, phosphorus, calcium and magnesium, adequate in terms of micro elements was reported (Albayrak, 2014; Özdoğan and Seferoğlu, 2015). Doğan and Erdal (2018) predicted that most of the soils were high in lime and low in organic matter content, with slight alkaline reaction, and had no risk of salinity, with loamy, clayey and clay-loam texture in their study, in which the fertility status of the soils where the grain production was conducted in Burdur province neighboring with Büyük Menderes Basin.
The objectives of this study are to determine the correlations between the physico-chemical properties and nutrient element contents of the wheat growing soils of Büyük Menderes Basin, which is the important agricultural potentials of Turkey on the basin level and provide basis for the different fertilizing studies in similar ecologies.

\section{Material and Method}

This research was conducted in Dutluca, Külçen, Avgan, Kurudere, Çamlıbel, Köseler and Hasköy locations, belonging to the district of Ulubey in Uşak province, Turkey $\left(38^{\circ} 25^{\prime}-29.1^{\prime}{ }^{\prime} \mathrm{N}, 2^{\circ} 17^{\prime}-23.8^{\prime}\right.$ 'E) in 2019 where the wheat growing was common in Büyük Menderes Basin (Figure 1). Uşak province, which is under the influence of the transition climate due to it's location and where mainly grain production with dry farming system comes to the forefront, has been placed as $5^{\text {th }}$ in wheat production in our country (TUIKK, 2018; Yavuz et al., 2020). The research material consisted of totally 50 soil samples taken from a depth of 0-30 cm (Jackson, 1958), 8 samples from Dutluca and 7 samples from each of the other locations.

The soil samples were air-dried and passed through a 2$\mathrm{mm}$ sieve for physico-chemical analysis.

Soil sand, clay and silt contents were determined by the hydrometric method (Bouyoucos, 1962); $\mathrm{pH}$ and total watersoluble salt were determined in a paste of soil saturated with water with a $\mathrm{pH}$ meter with a glass electrode and a conductometer (US Soil Survey Staff, 1951); lime contents were determined with a Scheibler calcimeter, and the amounts of organic matter were determined by wet digestion with $\mathrm{K}_{2} \mathrm{Cr}_{2} \mathrm{O}_{7}$ and $\mathrm{H}_{2} \mathrm{SO}_{4}$ (Reuterberg and Kremkurs, 1951). With regard to plant nutrient elements in the soil, total nitrogen was determined by the modified Kjeldahl method (Bremner 1965), and available phosphorus was determined colorimetrically after extraction with sodium bicarbonate (Olsen et al., 1954). Available $\mathrm{K}^{+}, \mathrm{Ca}^{++}, \mathrm{Na}^{+}, \mathrm{Mg}^{++}$contents were determined by ICP-OES after extraction with $1 \mathrm{~N}$ $\mathrm{NH}_{4} \mathrm{OAc}$. As for $\mathrm{Fe}, \mathrm{Mn}, \mathrm{Zn}, \mathrm{Cu}$, after extraction with 0.05 M DTPA + TEA were also predicted by ICP-OES (Isaac and Johnson, 1992). The results of the analysis were evaluated by using Table 1 .

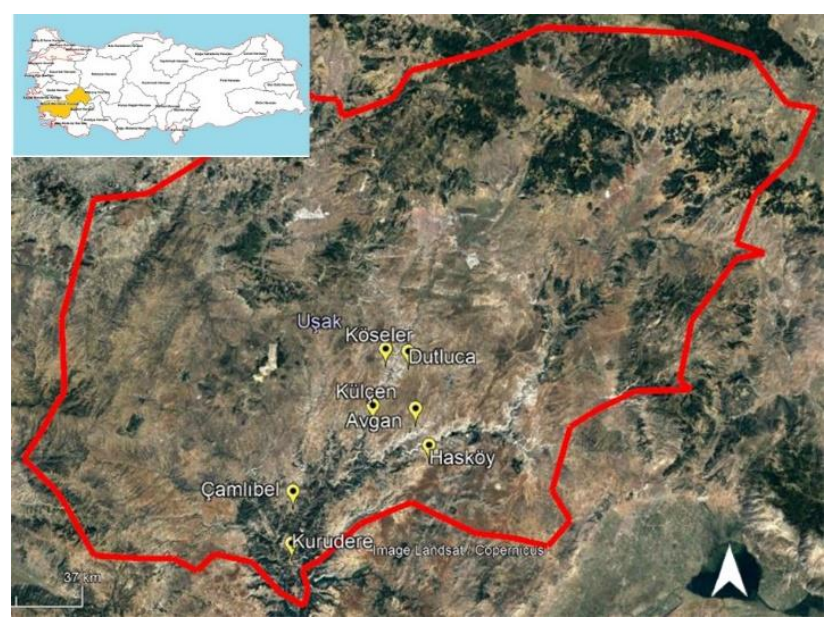

Figure 1. Research area 
Table 1. Descriptive statistics of physical and chemical properties of the research area

\begin{tabular}{l|ccccccc}
\hline Soil Properties & Min. & Max. & Mean & St. Error & CV* & Skewness & Kurtosis \\
\hline $\mathrm{pH}$ & 7.71 & 8.27 & 7.90 & 0.09 & 0.01 & 1.21 & 4.04 \\
$\mathrm{EC}\left(\mu \mathrm{S} \mathrm{cm}^{-1}\right)$ & 442 & 1285 & 873.9 & 219.51 & 0.25 & 0.12 & -0.99 \\
Lime & 2.48 & 69.40 & 20.38 & 14.72 & 0.72 & 1.59 & 2.81 \\
$\mathrm{OM}$ & 1.74 & 7.62 & 4.19 & 0.27 & 1.12 & 0.35 & 0.83 \\
Sand $(\%)$ & 72.8 & 40.08 & 59.04 & 7.16 & 0.12 & -0.52 & -0.09 \\
Silt & 8.72 & 24.72 & 16.54 & 3.51 & 0.21 & 0.51 & 0.11 \\
$\mathrm{Clay}$ & 13.92 & 39.92 & 24.42 & 6.49 & 0.27 & 0.81 & -0.11 \\
$\mathrm{~N}$ & 0.04 & 0.19 & 0.10 & 0.03 & 0.27 & 0.35 & 0.83 \\
$\mathrm{P}$ & 28.7 & 72.6 & 49.29 & 10.82 & 0.22 & -0.04 & -0.61 \\
$\mathrm{~K}$ & 82.52 & 631.2 & 261.92 & 132.6 & 0.51 & 1.47 & 2.11 \\
$\mathrm{Ca}$ & 5738 & 10730 & 7044.81 & 1018.5 & 0.14 & 1.88 & 4.16 \\
$\mathrm{Mg}\left(\mathrm{mg} \mathrm{kg}^{-1}\right)$ & 83.28 & 440.2 & 212.09 & 79.88 & 0.38 & 0.61 & 0.13 \\
$\mathrm{Fe}$ & 1.88 & 6.55 & 3.67 & 0.99 & 0.27 & 0.47 & 0.03 \\
$\mathrm{Cu}$ & 0.27 & 1.51 & 0.79 & 0.26 & 0.33 & 0.58 & 1.12 \\
$\mathrm{Zn}$ & 0.09 & 1.06 & 0.31 & 0.19 & 0.61 & 1.86 & 4.09 \\
$\mathrm{Mn}$ & 2.16 & 14.58 & 8.32 & 2.99 & 0.36 & -0.23 & -0.44 \\
\hline *:Coeficient Variation $<0.15:$ Low variability; $0.15-0.35:$ Average variability; $>0.35:$ High variability & &
\end{tabular}

Table 2. Some physical and chemical properties and nutrient content limits values of the soils (Zengin, 2012)

\begin{tabular}{|c|c|c|c|c|c|c|c|}
\hline Soil Properties & $\begin{array}{c}\text { Limit Value } \\
\text { Range }\end{array}$ & Evaluation & $\%$ & Soil Properties & $\begin{array}{c}\text { Limit Value } \\
\text { Range }\end{array}$ & Evaluation & $\%$ \\
\hline Texture & - & $\begin{array}{l}\text { Sandy-Loam } \\
\text { Sandy-Clay-Loam } \\
\text { Clay-Loam } \\
\text { Sandy-Clay }\end{array}$ & $\begin{array}{c}34 \\
60 \\
4 \\
2\end{array}$ & $\mathrm{EC}\left(\mathrm{dS} \mathrm{m} \mathrm{m}^{-1}\right)$ & $\begin{array}{c}0-4 \\
4-8 \\
8-15 \\
>15\end{array}$ & $\begin{array}{l}\text { Non saline } \\
\text { Slightly saline } \\
\text { Moderately saline } \\
\text { Strongly saline }\end{array}$ & $\begin{array}{c}100 \\
- \\
- \\
-\end{array}$ \\
\hline $\mathrm{CaCO}_{3}(\%)$ & $\begin{array}{l}1-5 \\
5-15 \\
15-25 \\
>25\end{array}$ & $\begin{array}{l}\text { Limy } \\
\text { Moderately } \\
\text { High } \\
\text { Very high }\end{array}$ & $\begin{array}{c}6 \\
34 \\
36 \\
22\end{array}$ & $\begin{array}{l}\text { Organic } \\
\text { Matter (\%) }\end{array}$ & $\begin{array}{c}<0,5 \\
0.5-1 \\
1.0-2.0 \\
2.0-3.0 \\
>3.0\end{array}$ & $\begin{array}{l}\text { Very low } \\
\text { Low } \\
\text { Medium } \\
\text { High } \\
\text { Very high }\end{array}$ & $\begin{array}{c}- \\
- \\
4 \\
4 \\
92\end{array}$ \\
\hline Total N (\%) & $\begin{array}{c}<0.045 \\
0.045-0.090 \\
0.090-0.170 \\
0.170-0.320 \\
>0.320\end{array}$ & $\begin{array}{l}\text { Very low } \\
\text { Low } \\
\text { Sufficient } \\
\text { High } \\
\text { Excessive }\end{array}$ & $\begin{array}{c}4 \\
30 \\
60 \\
6 \\
-\end{array}$ & $\begin{array}{l}\text { Available P } \\
\left(\mathrm{mg} \mathrm{kg}^{-1}\right)\end{array}$ & $\begin{array}{c}<2.5 \\
2.5-8.0 \\
8.0-25 \\
25-80 \\
>80\end{array}$ & $\begin{array}{l}\text { Very low } \\
\text { Low } \\
\text { Moderate } \\
\text { High } \\
\text { Very high }\end{array}$ & $\begin{array}{c}- \\
- \\
- \\
100\end{array}$ \\
\hline $\begin{array}{l}\text { Available K } \\
\left(\mathrm{mg} \mathrm{kg}^{-1}\right)\end{array}$ & $\begin{array}{c}50-140 \\
140-370 \\
370-1000\end{array}$ & $\begin{array}{l}\text { Insufficient } \\
\text { Sufficient } \\
\text { High }\end{array}$ & $\begin{array}{l}14 \\
76 \\
10\end{array}$ & $\begin{array}{l}\text { Available Ca } \\
\left(\mathrm{mg} \mathrm{kg}^{-1}\right)\end{array}$ & $\begin{array}{c}<380 \\
380-1150 \\
1150-3500 \\
3500-10000 \\
>10000\end{array}$ & $\begin{array}{l}\text { Very low } \\
\text { Low } \\
\text { Sufficient } \\
\text { High } \\
\text { Excessive }\end{array}$ & $\begin{array}{c}- \\
- \\
- \\
98 \\
2\end{array}$ \\
\hline $\begin{array}{l}\text { Available } \mathrm{Mg} \\
\left(\mathrm{mg} \mathrm{kg}^{-1}\right)\end{array}$ & $\begin{array}{c}<50 \\
50-160 \\
160-480 \\
480-1500 \\
>1500\end{array}$ & $\begin{array}{l}\text { Very low } \\
\text { Low } \\
\text { Sufficient } \\
\text { High } \\
\text { Excessive }\end{array}$ & $\begin{array}{c}- \\
26 \\
74 \\
- \\
-\end{array}$ & $\begin{array}{l}\text { Available Fe } \\
\left(\mathrm{mg} \mathrm{kg}^{-1}\right)\end{array}$ & $\begin{array}{c}<2.5 \\
2.5-4.5 \\
>4.5\end{array}$ & $\begin{array}{l}\text { Low } \\
\text { Medium } \\
\text { Sufficient }\end{array}$ & $\begin{array}{l}10 \\
64 \\
26\end{array}$ \\
\hline $\begin{array}{l}\text { Available } \mathrm{Cu} \\
\left(\mathrm{mg} \mathrm{kg}^{-1}\right)\end{array}$ & $\begin{array}{l}<0.2 \\
>0.2\end{array}$ & $\begin{array}{l}\text { Insufficient } \\
\text { Sufficient }\end{array}$ & $\begin{array}{c}- \\
100\end{array}$ & $\begin{array}{l}\text { Available } \mathrm{Zn} \\
\left(\mathrm{mg} \mathrm{kg}^{-1}\right)\end{array}$ & $\begin{array}{c}<0.2 \\
0.2-0.7 \\
0.7-2.4 \\
2.4-8 \\
>8\end{array}$ & $\begin{array}{l}\text { Very low } \\
\text { Low } \\
\text { Sufficient } \\
\text { High } \\
\text { Very high }\end{array}$ & $\begin{array}{c}20 \\
74 \\
6 \\
- \\
-\end{array}$ \\
\hline $\begin{array}{l}\text { Available Mn } \\
\left(\mathrm{mg} \mathrm{kg}^{-1}\right)\end{array}$ & $\begin{array}{c}4 \\
4-14 \\
14-50\end{array}$ & $\begin{array}{l}\text { Very low } \\
\text { Low } \\
\text { Sufficient }\end{array}$ & $\begin{array}{c}10 \\
88 \\
2\end{array}$ & $\mathrm{pH}$ & $7.5-8.5$ & Slightly Alkaline & 100 \\
\hline
\end{tabular}


The data obtained belonging to physico-chemical properties and plant nutrient contents of soils subjected to normality analysis with Shapiro-Wilk test through the use of IBM SPSS 25.0 software. Correlations between data determined by Spearman correlation test (Table 2).

\section{Results and Discussion}

The descriptive analysis of some soil properties of 50 soil samples were shown in Table 1 . When the parameters were evaluated in terms of skewness; sand \%, available phosphorous and managanese showed negatively skewed while the other parameters showed positively skewed distribution. The positively skewed distribution feature indicates that most of the values for the relevant parameters are below the mean (Köksal, 2002).

The coefficient of variability which is accepted as an important indicator of the variability in soil properties, is classified as low $(<0.15)$, medium $(0.15-0.35)$ and high $(>0.35)$ according to some researchers (Wilding, 1985; Mulla and Mc Bratney, 2000; Sağlam, 2013). In accordance with these results, among the soil properties examined, only $\mathrm{pH}$, sand $\%$ and available calcium contents were low; EC, silt \%, clay \%, total nitrogen, available phosphorous, iron and copper contents were medium and the other parameters showed high variability was seen in Table 1.

Classification of soil physical, chemical properties and nutrient contents according to limit values were given in Table 2 .

Soils of the research area which are sandy-clay-loam textured in general, all of them with slightly alkaline reaction and have no risk of salinity. All the soils of the region are suitable for optimum growth of wheat showed neutral-slightly alkaline ( $\mathrm{pH}$ 6.5-7.8) reaction (Çolakoğlu, 1985). Aydin et al., (2008) reported that the soil reactions showed changings in the range of 7.16-8.77 in Lower Büyük Menderes Basin where the second crop of maize growing was conducted. Similarly, in another research in which the nutritional status of walnut orchards in Uşak province was examined, the soils of the research area were generally loam and clay-loam textured, had neutral/slightly alkaline reaction and no risk of salinity was reported (Y1ldiz and Uygur, 2016). Our results have been coincided with the results of different studies carried out in the same ecology. $70 \%$ of the research area soils have moderate/high lime content and $92 \%$ of these soils were found to be rich in organic matter. In this regard, the wheat is known to be well grown in the soils which are calcerous and rich in organic matter and nutrient elements, therefore suitable for basin soils. As a matter of fact, great proportion $(61 \%)$ of the region's soils were calcerous and moderate (75\%) in terms of organic matter was reported (Y1ldiz and Uygur, 2016). In another study conducted in a similar ecology (Çerçioğlu, 2016), 17\% of the Simav region soils were moderate and $26 \%$ of them were high in lime content while they were generally in well status due to organic matter was reported. In arid region soils occurred on calcerous main material, as a result of increased calcium concentration and $\mathrm{pH}$ it should be noticed on micro element fertilisations because of the possible antagonistic effects could lead to uptake of phosphorous and micro elements (Kacar et al., 2006). When the soils of the study area were evaluated in terms of nutrient content (Zengin, 2012), total nitrogen of $66 \%$ and available potassium content of $86 \%$ were adequate/high; the available magnesium content of $74 \%$ was adequate while available phosphorous, copper and calcium contents of all the soils were found to be sufficient (Table 2). In accordance with available iron amounts, $64 \%$ of region soils were medium while zinc (74\%) and manganese $(88 \%)$ amounts of most of them were insufficient (Table 2). Özdoğan and Seferoğlu (2015), reported that $70 \%$ of Lower Büyük Menderes Basin's soils were sufficient in terms of nitrogen, all of them were sufficient in available phosphorous and copper while most of them were sufficient in available calcium (94\%), magnesium (89\%), iron (88\%) and zinc (92\%) contents. Our findings were in parallel with notified values, except available zinc contents. Similar to our findings, $96 \%$ of the basin's soils were found to be insufficient in terms of available zinc was reported in a study in which the nutrition status of walnut orchards in Uşak province (Y1ld1z and Uygur, 2016). Moreover, available $\mathrm{K}, \mathrm{Mg}, \mathrm{Ca}$ and $\mathrm{Cu}$ contents of grain cultivating soils found to be sufficient in Isparta province where the ecological conditions are resembling with our research area (Alaboz ve ark., 2019).

According to correlation analysis, negative correlations were determined between soil $\mathrm{pH}$ and $\mathrm{EC}\left(-0.363^{* *}\right), \mathrm{N}(-$ $\left.0.313^{* *}\right), \mathrm{K}\left(-0.338^{*}\right)$ ve $\mathrm{Zn}\left(-0.297^{*}\right)$ contents (Table 3$)$. Soil $\mathrm{pH}$ significantly influences the plant growth by limiting the availability of nutrient elements (Akça et al., 2015). Higher soil $\mathrm{pH}$ has been complicated the availability of micro elements therefore diminished the usefulness for plants. From this point of view, relationships between $\mathrm{pH}$ and available amounts of mentioned micro elements that reported by different researchers (Çelik and Katkat, 2005; Parlak et al., 2008; Karaduman and Çimrin, 2016; Bayram, 2019) were in parallel with our findings. Significant positive correlations determined between EC values of soils and $\mathrm{K}\left(\mathrm{r}: 0,292^{*}\right), \mathrm{Ca}\left(0.376^{* *}\right), \mathrm{Zn}\left(0.343^{*}\right)$ contents. Our results have been overlapped with the reported correlations of similar studies conducted in different ecologies (Karaduman and Çimrin, 2016; Bayram, 2019). Strong negative correlations were predicted between soil lime contents and $\mathrm{Mg}(-0.421 * *), \mathrm{Fe}(-0.393 * *), \mathrm{Cu}(-$ $0.515 * *)$ contents. The $\mathrm{Ca}^{++}$amount overcoming to predominant in soil due to the high $\mathrm{CaCO}_{3}$ level caused by occurance of a negative correlation diminishing the adsorbtion of $\mathrm{Mg}^{++}$by soil colloids, which are in the same valence, competing with $\mathrm{Ca}^{++}$. On the other hand, increasing $\mathrm{pH}$ related to with high lime content negatively influenced the uptake of micro nutrient elements (Bayram, 2016). Strong positive correlations were determined between the organic matter contents of research area soils and $\mathrm{N}\left(1.00^{* *}\right), \mathrm{K}\left(0.659^{* *}\right), \mathrm{Cu}\left(0.315^{*}\right), \mathrm{Zn}(0.387 * *)$ and $\mathrm{Mn}\left(0.404^{* *}\right)$ contents. The increasing amount of organic matter in soils increased the adsorption of nutrient elements by increasing the soil adsorption capacity (Atalay, 1988; Çimrin and Boysan, 2006; Bayram, 2019). Negative correlations were observed between sand contents and silt $(-0.427 * *)$ and clay $(-0.873 * *)$ contents while positive correlations between $\mathrm{Mn}(0.359 *)$ contents of soils. Negative correlations were determined between silt and $\mathrm{Mg}(-0.290 *)$, clay and $\mathrm{K}(-0.379 * *), \mathrm{Mn}(-0.330 *)$ contents of soils. 
Table 3. Relations Between Some Physical-Chemical Properties of the Soils and its Nutrient Contents

\begin{tabular}{|c|c|c|c|c|c|c|c|c|}
\hline & $\mathrm{pH}$ & $\mathrm{EC}$ & Lime & OM*** & Sand & Silt & Clay & $\mathrm{N}$ \\
\hline $\mathrm{pH}$ & 1 & & & & & & & \\
\hline $\mathrm{EC}$ & $-0.363 * *$ & 1 & & & & & & \\
\hline Lime & -0.120 & -0.222 & 1 & & & & & \\
\hline $\mathrm{OM}$ **** & $-0.313^{*}$ & 0.203 & -0.087 & 1 & & & & \\
\hline Sand & -0.156 & 0.049 & 0.182 & 0.167 & 1 & & & \\
\hline Silt & -0.048 & 0.070 & 0.050 & 0.073 & $-0.427 * *$ & 1 & & \\
\hline Clay & 0.198 & -0.091 & -0.227 & -0.223 & $-0.873 * *$ & -0.069 & 1 & \\
\hline $\mathrm{N}$ & $-0.313 * *$ & 0.203 & -0.090 & $1.00 * *$ & 0.163 & 0.72 & -0.219 & 1 \\
\hline $\mathrm{P}$ & -0.100 & 0.070 & 0.043 & 0.226 & -0.085 & 0.076 & 0.053 & 0.227 \\
\hline K & $-0.338^{*}$ & $0.464 * *$ & -0.277 & $0.659 * *$ & 0.223 & 0.245 & $-0.379 * *$ & $0.657 * *$ \\
\hline $\mathrm{Ca}$ & 0.015 & $0.376^{* *}$ & 0.001 & 0.040 & 0.020 & -0.186 & 0.078 & 0.040 \\
\hline $\mathrm{Mg}$ & 0.045 & 0.124 & $-0.421 * *$ & -0.089 & 0.033 & -0.060 & -0.069 & -0.089 \\
\hline $\mathrm{Fe}$ & 0.144 & 0.181 & $-0.393 * *$ & 0.182 & -0.227 & $-0.290 *$ & $0.407 * *$ & 0.184 \\
\hline $\mathrm{Cu}$ & -0.045 & 0.148 & $-0.515^{* *}$ & $0.315^{*}$ & 0.222 & -0.263 & -0.103 & $0.313^{*}$ \\
\hline $\mathrm{Zn}$ & $-0.297^{*}$ & $0.343^{*}$ & 0.193 & $0.387 * *$ & 0.157 & -0.068 & -0.137 & $0.386 * *$ \\
\hline \multirow[t]{2}{*}{$\mathrm{Mn}$} & -0.062 & 0.221 & -0.226 & $0.404 * *$ & $0.359 *$ & -0.122 & $-0.330 *$ & $0.403 * *$ \\
\hline & $\mathrm{P}$ & $\mathrm{K}$ & $\mathrm{Ca}$ & $\mathrm{Mg}$ & $\mathrm{Fe}$ & $\mathrm{Cu}$ & $\mathrm{Zn}$ & $\mathrm{Mn}$ \\
\hline $\mathrm{P}$ & 1 & & & & & & & \\
\hline K & 0.074 & 1 & & & & & & \\
\hline $\mathrm{Ca}$ & -0.148 & 0.090 & 1 & & & & & \\
\hline $\mathrm{Mg}$ & -0.202 & 0.204 & -0.234 & 1 & & & & \\
\hline $\mathrm{Fe}$ & -0.004 & 0.052 & $0.385 * *$ & $0.351 *$ & 1 & & & \\
\hline $\mathrm{Cu}$ & -0.064 & $0.457 * *$ & -0.109 & $0.464 * *$ & $0.382 * *$ & 1 & & \\
\hline $\mathrm{Zn}$ & $0.294 *$ & $0.399 * *$ & -0.079 & -0.189 & -0.050 & 0.106 & 1 & \\
\hline Mn & -0.012 & $0.461 * *$ & 0.138 & 0.264 & $0.311^{*}$ & $0.619 * *$ & 0.268 & 1 \\
\hline
\end{tabular}

On the contrary, clay and Fe contents of soils showed a positive correlation $(0.407 * *)$. When the correlations between plant nutrients with each other, positive correlations found between total $\mathrm{N}$ and available $\mathrm{K}$ (0.657**), $\mathrm{Cu}(0.313 *), \mathrm{Zn}(0.386 * *)$ and $\mathrm{Mn}(0.403 * *) ; \mathrm{P}$ and $\mathrm{Zn}(0.294 *) ; \mathrm{K}$ and $\mathrm{Cu}(0.457 * *), \mathrm{Zn}(0.399 * *)$ and $\mathrm{Mn}\left(0.461^{* *}\right)$; Ca and $\mathrm{Fe}\left(0.385^{* *}\right), \mathrm{Mg}$ and $\mathrm{Fe}\left(0.351^{*}\right)$ and $\mathrm{Cu}(0.464 * *) ; \mathrm{Fe}$ and $\mathrm{Cu}(0.382 * *)$ and $\mathrm{Mn}\left(0.311^{*}\right)$; $\mathrm{Cu}$ and $\mathrm{Mn}(0.619 * *)$ contents of soils respectively. Similar positive correlations (e.g. available $\mathrm{Fe}-\mathrm{Cu}$; $\mathrm{Cu}-\mathrm{Mn}$ contents of soils) were reported in many different studies (Tarakçıŏlu et al., 2003, Başaran and Okant, 2005; Çimrin and Boysan, 2006; Turan et al., 2010; Akça et al., 2015).

\section{Conclusion}

Our results showed that soils of Büyük Menderes Basin in the inner Aegean region are generally proper for wheat cultivation, which were sandy-clay-loam textured, with slightly alkaline reaction, no risk of salinity and rich in lime and organic matter. In terms of macro elements, the basin soils showed deficiency only for total nitrogen as 34\% while the greatest part of them are poor in $\mathrm{Zn}$ and $\mathrm{Mn}$. The results obtained indicate that nitrogen fertilization should be paid attention to the basin soils, as it is an element that directly affects the protein content, which is an important quality criterion in wheat. It is also important to eliminate micro element deficiencies due to high $\mathrm{pH}$ with foliar applications at the proper time and amount.

\section{References}

Akça MO, Türkmen F, Taşkın MB, Soba MR, Öztürk HS. 2015. Ankara Üniversitesi Kalecik Araştırma ve Uygulama Çiftliği topraklarının verimlilik durumlarının incelenmesi. Toprak Bilimi ve Bitki Besleme Dergisi, 3: 54-63.

Alaboz P, Demir S, Başayiğit L, Işıldar AA. 2019. Isparta İli Büyük Toprak Gruplarına Göre Tahıl Yetiştirilen Toprakların Bazı Özelliklerinin Belirlenmesi. Tarla Bitkileri Merkez Araştırma Enstitüsü Dergisi, 28: 67-79.

Albayrak H. 2014. Aydın merkez ilçesi pamuk üretiminde yetiştirme koşullarının verim, lif ve tohum özellikleri üzerine etkisi. Yüksek Lisans Tezi, Fen Bilimleri Enstütüsü, Adnan Menderes Universitesi, Aydin.

Atalay IZ. 1988. Gediz havzası rendzina topraklarının besin elementi durumu ve bunların bazı toprak özellikleri ile ilişkileri. Ege Üniversitesi Ziraat Fakültesi Dergisi, 25: 173184.

Aydın M, Başal H, Şeker G, Merken Ö, Kaptan MA. 2008. Aşağ1 Büyük Menderes Vadisi topraklarında yetişen ikinci ürün misırın beslenme durumu, gübre uygulamaları ve sorunları. In: Gezgin S, Zengin M (editors). 4. Ulusal Bitki Besleme ve Gübre Kongresi, Konya, 8-10 Ekim 2008, s.174-183.

Bayram SE. 2019. The Relationships Between Some PhysicalChemical Properties and the Nutrient Content of Soils Where Tobacco is Cultivated in the Gediz Basin. Turkish Journal of Agriculture-Food Science and Technology, 7: 1917-1923. doi: 10.24925/turjaf.v7i11.1917-1923.2892

Bayram SE, Elmacı ÖL, Özden N. 2016. İzmir ili güney hatt1 şeftali (Prunus persica L.) bahçelerinin beslenme durumlarının incelenmesi. Tekirdağ Ziraat Fakültesi Dergisi, 13: 27-35. 
Başaran M, Okant M. 2005. Bazı Toprak Özelliklerinin Eldivan Yöresinde Yetiştirilen Kirazların Beslenme Durumu Üzerine Etkisi. Tarım Bilimleri Dergisi, 11(2): 115-119. doi 10.1501/Tarimbil_0000000418

Bouyoucos GJ. 1962. Hydrometer Method Improved for Making Particle Size Analysis of Soil. Agronomy Journal, 54: 464465. doi: 10.2134/agronj1962.00021962005400050028x

Bremner JM. 1965. Total Nitrogen. In: Black CA (editor). Methods of Soil Analysis. Part 2. American Society Of Agriculture Inc., Publisher, Madison, Wisconsin - USA. p: 1149 - 1178.

Çelik H, Katkat AV. 2005. Bursa İli Şeftali Yetiştiriciliği Yapılan Tarım Topraklarının Potasyum Durumu ve Demir Klorozu ile İlişkisi. Tarımda Potasyumun Yeri ve Önemi Çalıştayı, s: 7484.

Çerçioğlu M. 2019. Simav yöresi tarım topraklarının bazı fiziksel ve kimyasal özelliklerinin araştırılması. Toprak Bilimi ve Bitki Besleme Dergisi, 7: 57-63. doi: 10.33409/tbbbd.595167

Çimrin KM, Boysan S. 2006. Van yöresi tarım topraklarının besin elementi durumları ve bunların bazı toprak özellikleri ile ilişkileri. Yüzüncü Yıl Üniversitesi Tarım Bilimleri Dergisi, 16: 105-111.

Çolakoğlu H. 1985. Gübre ve gübreleme. E.Ü. Zir. Fak. Teksir no: 17 - I. Bornova-İzmir.

Doğan A, Erdal İ, 2018. Burdur ili tahıl yetiştirilen toprakların verimlilik durumlarının belirlenmesi. Toprak Bilimi ve Bitki Besleme Dergisi, 6: 39-45.

Düzbastılar, M. 1984. Büyük Menderes Havzası Pamuk Tarımı Yapılan Toprakların Gübreleme Yönünden Durumu. s. 6-3, İzmir.

FAO, 2021. Food and Agriculture Organization of the United Nations. FAOSTAT. Available from: http://www.fao.org/faostat/ [Available date: 5.07.2021].

Genç Ö. 2004. Uşak ili uygun yatırım alanları araştırması. Türkiye Kalkınma Bankası A.Ş. ISBN 975-7406-41-4.

Isaac RA, Johnson WC. 1992. Determination of $\mathrm{P}, \mathrm{K}, \mathrm{Ca}, \mathrm{Mg}$, $\mathrm{Mn}, \mathrm{Fe}, \mathrm{Al}, \mathrm{B}, \mathrm{Cu}$, and $\mathrm{Zn}$ in Plant by Emission Spectroscopy. In: Plank CO (editor). Plant Analysis Reference Procedures for Southern Region of the United States, pp. 38-42. ISBN 158161-368-7 (Print).

Jackson ML. 1958. Soil Chemical Analysis. Prentice Hall, Inc. Englewood Cliffs, New Jersey, USA, pp. 1-498.

Tarakçıŏlu C, Yalçın SR, Bayrak A, Küçük M, Karabacak H. 2003. Ordu yöresinde yetiştirilen findık bitkisinin beslenme durumunun toprak ve yaprak analizleriyle belirlenmesi. Tarım Bilimleri Dergisi, 9: 13- 22. doi: 10.1501/Tarimbil_0000000338.

Tugay E, Sepetoğlu H. 1983. Tarla bitkileri. E.Ü. Zir. Fak. Teksir no: 74-II. Bornova.

TUİK 2018. "Uşak ili buğday üretimi”" Türkiye İstatistik Kurumu, https://biruni.tuik.gov.tr/medas $/$ kn $=92 \&$ locale $=\operatorname{tr} \quad$ (Erişim tarihi: 29.09.2021)
Turan MA, Katkat AV, Özsoy G, Taban S. 2010. Bursa ili alüviyal tarım topraklarının verimlilik durumları ve potansiyel beslenme sorunlarının belirlenmesi. Bursa Uludağ Üniversitesi Ziraat Fakültesi Dergisi, 24: 115-130.

Kacar B, Katkat AV, Öztürk Ş. 2006. Bitki Fizyolojisi: 2. bask1. Nobel Yayınları, Ankara. ISBN 975-564-133-5.

Karaduman A, Çimrin K. 2016. Gaziantep Yöresi Tarım Topraklarının Besin Elementi Durumları ve Bunların Bazı Toprak Özellikleri ile İlişkileri. KSÜ Doğa Bilimleri Dergisi, 19: 117-129. doi: 10.18016/ksudobil.254785

Karaman MR, 2012. Bitki Besleme, GÜBRETAŞ Rehber Kitaplar Dizisi:2, ISBN 978-605-87103-2-0.

Köksal BA. 2002. İstatistik Analiz Metotları. Çağlayan Kitabevi. Beyoğlu, İstanbul. ISBN 9789754360523.

Mulla DJ, Mc Bratney AB. 2000. Soil Spatial Variability. Handbook of SoilScience CRS Pres. 978-9022008911.

Olsen SR, Cole CV, Watanabe FS, Dean LA. 1954. Estimation of Available Phosphorus in Soils by Extraction with Sodium Bicarbonate. U. S. Department of Agriculture Circular No. 939. Banderis, A. D. D. H. Barter and K. Anderson. Agricultural and Advisor. ISBN 978-1391307107

Özdoğan N, Seferoğlu S. 2015. Aşağı büyük menderes havzasında sanayi domatesi yetiştiriciliği yapılan arazilerin toprak özellikleri. Adnan Menderes Üniversitesi Ziraat Fakültesi Dergisi, 12: 109-115.

Parlak M, Fidan A, Kızılcık İ, Koparan H. 2008. Eceabat ilçesi tarım topraklarının verimlilik durumlarının belirlenmesi. Ankara Üniversitesi Ziraat Fakültesi Tarım Bilimleri Dergisi, 14:394-400.

Reuterberg E, Kremkus F. 1951. Bestimmung von Gesamthumus und Alkalischen Humusstoffen im Boden, Zeitschrift für Pflanzenernahrung, Düngung und Bodenkunde. Verlag Chemie GmbH. Weinheim.

Sağlam M. 2013. Çok değişkenli istatistiksel yöntemler ile toprak özelliklerinin gruplandırılması. Toprak Su Dergisi: 7-14.

U.S Soil Survey Staff, Soil Survey Manual. 1993. U.S. Dept. Agr. Handbook 18. U.S Govt. Printing Office. Washington DC. USA. ISBN 978-0359573684.

Yavuz DÖ, Lökçü AO, Sinan D. 2020. Uşak İli Buğday Yetiştiriciliğinde Yabancı Ot Sorunlarının Belirlenmesi. Turkish Journal of Weed Science, 23: 52-62.

Yıldız E, Uygur V. 2016. Uşak ili ceviz bahçelerinin mineral beslenme durumları. Süleyman Demirel Üniversitesi Ziraat Fakültesi Dergisi, 11: 70-78.

Wilding LP. 1985. Spatial variability: It's documentation, accommodation and implication to soil surveys. In: D.R. Nielsenand, J. Bouma (Eds.), Soil Spatial Variability, Pudoc, Wageningen, pp:166-194.

Zengin M. 2012. Toprak ve Bitki Analiz Sonuçlarının Yorumlanmasında Temel İlkeler In: Karaman MR (editör). Bitki Besleme. Gübretaş Rehber Kitaplar Dizisi:2, ss. 837961. ISBN 978-605-87103-2-0 (Print) 